\begin{tabular}{|l|l|l||}
\hline \multicolumn{2}{|c|}{ PublisherInfo } \\
\hline \hline PublisherName & $:$ & BioMed Central \\
\hline \hline PublisherLocation & $:$ & London \\
\hline \hline PublisherImprintName & $:$ & BioMed Central \\
\hline \hline
\end{tabular}

\title{
Analysis of protein sequences
}

\begin{tabular}{|l|l|l||}
\hline \multicolumn{2}{|c|}{ ArticleInfo } \\
\hline \hline ArticleID & $:$ & 3599 \\
\hline \hline ArticleDOI & $:$ & $10.1186 /$ gb-2000-1-1-reports225 \\
\hline \hline ArticleCitationID & $:$ & reports225 \\
\hline \hline ArticleSequenceNumber & $:$ & 90 \\
\hline \hline ArticleCategory & $:$ & Web report \\
\hline \hline ArticleFirstPage & $:$ & 1 \\
\hline \hline ArticleLastPage & $:$ & 4 \\
\hline \hline & & RegistrationDate : 1999-11-23 \\
& $:$ & Received \\
ArticleHistory & $:$ 1999-11-23 \\
\hline \hline ArticleCopyright & $:$ & BioMed Central Ltd2000 \\
\hline \hline ArticleGrants & $:$ & \\
\hline \hline ArticleContext & $:$ & 130591111 \\
\hline \hline
\end{tabular}




\section{Abstract}

Several programs to predict sequence and structural features of a protein can be run simultaneously on the PredictProtein server.

\section{Mirror sites}

PredictProtein mirror sites.

\section{Content}

Several programs to predict sequence and structural features of a protein can be run simultaneously on the PredictProtein server. The programs have been contributed by various authors. MaxHom is a program that searches databases for homologous proteins using BLAST and performs a multiple alignment of the most closely related proteins. Homology to known protein domains is investigated by running searches against ProSite and ProDom. PHDsec and PHDacc are used to predict secondary structure and solvent accessibility, respectively. Other structural characteristics that can be investigated are globularity (Globe), transmembrane helices (PHDhtm), coiled-coil regions (Coils) and fold (Topits).

\section{Navigation}

The simple structure of the site, with three main submission forms (default, advanced, expert) makes navigation easy. In fact, the server would benefit from more links to files with information on the algorithms and basic features of the different programs. Instead, such information partially appears in the output files, making them unnecessarily long.

\section{Reporter's comments}




\section{Timeliness}

It was not clear when the site was last updated, but the SWISS-PROT version used to do BLAST searches was up to date (release 38.0, July 1999).

\section{Best feature}

Different characteristics of a protein can be investigated in a matter of minutes. A very useful feature is the construction of multiple alignment from BLAST hits by MaxHom.

\section{Worst feature}

The output options are not well organized so it is not always clear which programs are running.

\section{Wish list}

It would be useful to be able to get the results directly from the web browser, instead of their being sent by e-mail. Also, the service would improve by adding other databases, besides SWISS-PROT, to perform BLAST searches.

\section{Related websites}

More on protein prediction can be found at Expasy and the Protein sequence analysis protein structure prediction server.

\section{Table of links}

The PredictProtein server

PredictProtein mirror sites 
Expasy

Protein sequence analysis protein structure prediction

\section{References}

1. The PredictProtein server.

This PDF file was created after publication. 